KAIROS ELT JOURNAL, Vol. 2, No. 2, August 2018

Copyright $\odot 2018$, ISSN: 2580-4278

\title{
THE USE OF WORDS MATCHING GAME TO IMPROVE STUDENTS' VOCABULARY MASTERY OF THE FIRST GRADE STUDENTS OF SMP SANTO PETRUS MEDAN
}

\author{
Veronika Matondang, Erikson Saragih, Novalina Sembiring \\ Catholic University of Saint Thomas
}

\begin{abstract}
This research is conducted in order to improve students' vocabulary mastery in the easiest way through using words matching game of the first grade students of SMP Santo Petrus Medan. In conducting this research, the researcher used Classroom Action Research (CAR) as the method of research. This research consisted of two cycles and each cycle consisted of four steps, they were planning, action, observation and reflecting. Each cycle was conducted in three meetings, so the researcher conducted this researcher in six meetings for one month and three weeks. The data were in the form of qualitative and quantitative data. The qualitative data was analyzed the learning teaching process. The quantitative data was to count the students' score in pre-test and post-test. The students' responses showed that they were interested in learning vocabulary through words matching game. Morever, the students' achievements in pre-test and post-test showed a significant improvement. The students' average score in pre-test was $49.03 \%$, the average score in formative test in cycle 1 was $73 \%$, and the average score in post-test end program improved about $77.84 \%$. From this result, the researcher concluded that using words matching game of the first grade students of SMP Santo Petrus Medan can improve students' vocabulary mastery.
\end{abstract}

Keywords: word matching game, vocabulary mastery

\section{INTRODUCTION}

Vocabulary is not particular subject for the students to learn, but it has been taught within the lessons of listening, speaking, reading, and writing (Schmitt, 2000).

Vocabulary is one of the language aspects which should be learnt by the students. Nation (in Nunan, 2003:130) states that words are clearly vocabulary.

Vocabulary mastery is important for language learners in learning the whole language. Willis (2008: 80) states that when students build vocabulary mastery, they can more effectively communicate their ideas, knowledge and voice. When learners try to develop their vocabulary mastery, their thinking and understanding of speaking will improve. Then, they can communicate effectively.

Vocabulary and mastery are parts of set in learning vocabulary, mastery is clearly shown by learners' ability in expressing vocabulary that known with understanding. It is also shown by their ability of making sentences using vocabulary. Vocabulary mastery is purposed of learning vocabulary, because when learners mastery vocabulary they are able to use it in daily life.

Most students are taught not to memorize vocabulary, usually if it is taught by appropriate methods, the students will easily receive a lesson. For example, the more often a word is successfully retrieved from memory, the easier it becomes to recall it (Thornbury, 2002: 102). In this case, the writer tries to build the spirit of the students to increase their vocabulary mastery by words matching game. This game provides opportunities for students to study while play fun game in the classroom. Using game in learning English is very important in learning English in order to make students easily to catch the material (Limbong, 2013).

Learning vocabulary through games has attaines a lot of attention. Derakhshan and Khatir (2015:39) state that games are beneficial in vocabulary learning because they enchance

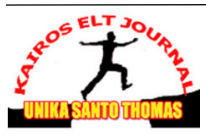


KAIROS ELT JOURNAL, Vol. 2, No. 2, August 2018

Copyright $\odot 2018$, ISSN: 2580-4278

students' ability to memorize words, encourage students' interaction, improve their comunicative skills and enhance students' motivation. Games also can help the teachers to create contexts in which the language is useful and meaningful.

Based on the writer's observation it is found that, there are several problems faced by the first grade students of SMP Santo Petrus Medan. The problems are as follows: 1) the students' enthusiasm and active learning are still not visible. 2) the students rarely ask questions, although teachers often request the students to ask if they have problems or the explanations are not clear or less understood. 3) their activities in working or training English language learning are also still poor. 4) the lack of courage to work on and present it in front of the class. 5) Students feel bored, because they are only positioned as listeners. 6) the lack of the subject matter mastery, especially in vocabulary. 7) the learning processes and strategies used by the teacher are still monotonous and less interesting. 8) they lack facilities to improve their English learning.

Based on the observation, the researcher wants to conduct a research to know how the use of words matching game can improve vocabulary mastery of the first grade students of SMP Santo Petrus Medan. This research is conducted to describe the process of improving students' vocabulary mastery of the first grade students of SMP Santo Petrus Medan. This research is important to do to know whether there is a significant use of words matching games to improve students' vocabulary mastery of the first grade students of SMP Santo Petrus Medan.

There are some previous researchers who conducted research on student used the words matching game to improve the students' vocabulary mastery. Iriyani in 2013 who conducted a research entitled "Improving Students' Vocabulary Achievement through Make a Match Method" concluded that based on the data, the students' scores got improvement in every cycle. In test I, the mean of the students' score was 59 while test II, the mean of the students' score was 70.5 and in test III the mean of the students' score was 77.3. It was found that the teaching vocabulary through Make a Match Method improve the students' vocabulary Achievement. Uswatun $\mathrm{H}$ in 2015 who conducted a research entitled "The Use of Words Matching Game to Improve Students' Vocabulary Mastery" concluded that the use of words matching game could not improve students' vocabulary mastery effectively because after being given the treatment, the writer found that the word matching game did not give significantly positive effect on the students' vocabulary. It can be seen through the result of the t-test gained was 1.629 with the degree of freedom (df) 60 . With t-test result, the writer compared it to t-table in .05 (95\%) and $.01(99 \%)$ level. In df 60 , the significant level of .05 is 2,000 while .01 is 2,660. T-test was lower than t-table in both levels. Therefore, the null hypothesis that say "there is no significant effect of word matching game in improving students' vocabulary" is failed to be rejected.

To increase the vocabulary mastery we need media. One of them is game. Game is an activity that can be done by students to have some fun. It can make the students more focus in learning, because they do not feel that they are forced to learn. The use of games is to attract the student to learn English because it is fun and make them want to have experiment, discover and interact with their environment (Lewis and Bedson, 1999).

There are many games that can be applied in teaching vocabulary, one of which is word game. Word game is a game that requires players to play with the word in various orders. It can be matching the word with the picture, filling the puzzle box with the right word based on its definition, and the like. The use of word game in teaching the students vocabulary will provide not only enjoyment but also to enrich their vocabulary and to provide the chance to practice what they have already known.

Based on the background, the writer is interested in increasing the students' vocabulary mastery by using words matching games at the first grade students of SMP Santo Petrus Medan of Academic Year 2016 / 2017. 


\section{REVIEW OF LITERATURE Definition of Vocabulary}

Vocabulary is one of aspects in English. It is very important for studying English. Learner who just learns grammar without vocabulary will be difficult to convey what he or she wants to say. Vocabulary is then an essential component learned in language learning. In relation to this, the linguist David Wilkins in Thornbury (2002 : 13) stated that without grammar very little can be conveyed, without vocabulary nothing can be conveyed. The most important point of the statement above is that mastering vocabulary for students is the main component in order to learn a language successfully. In listening, students' vocabulary mastery influences their understanding towards teacher's speech, class discussion, and other speeches. The words that they choose in speaking affect how well they deliver a message. In reading, students' vocabulary mastery affects their ability to understand and comprehend a text. In addition, dealing with writing, students' vocabulary mastery also influences how clear they convey their thought to the reader. In short, vocabulary mastery takes an important role in equipping the students to be able to communicate in English.

According to Scrivener (1994:31) vocabulary is a powerful carrier of meaning. A learner, recognizing the communicative power of vocabulary, might reasonably aim to acquire a working knowledge of a large words. Vocabulary can help the students to improve their skill in reading, writing, listening and speaking. Without vocabulary, the students can not communicate well.

Based on those explanation, the writer can say that vocabulary contains not only list of words but also all of information about using words, and meaning of the words in a language. So, it becomes a basic for people to communicate, because without vocabulary an idea cannot be given in communication.

\section{Kinds of Vocabulary}

Based on Thornbury (2002:22) two kinds of English vocabulary to teach are productive and receptive vocabulary. Productive is the lexical items, which the students can use appropriately in speaking and writing. It is also called as active vocabulary, although, in fact, it is more difficult to put into practice. It means that to use the productive vocabulary, the students are supposed to know how to pronounce it well, they must know and be able to use grammar of the language target, they are also hoped to familiar with collocation and understand the connotation meaning of the words. This type is often used in speaking and writing skill. For example he or she can produce new words when he or she write something and speak to another people. Receptive vocabulary is the lexical items that the students can recognize and understand when they meet them in the context of reading and listening materials. It's also called as passive vocabulary. Passive vocabulary or comprehension consists of the words comprehended by the people, when they read and listen. Receptive vocabulary knowledge refers to the ability to understand a word when it is heard or seen for example when someone ever hear a song and see the lyrics so she or he can understand what she or he hear and receive the new word from she or he see the lyrics.

\section{The Importance of Vocabulary}

Vocabulary is very important in learning foreign language, because it is a basic knowledge to achieve comprehension in learning and using the language. According to Scrivener (1994: 75) there are five roles of vocabulary, they are:

a. Vocabulary is very important and needed to be dealt with systematically its own right.

b. We need to distinguish between vocabularies for productive use receptive recognition.

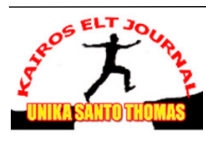


KAIROS ELT JOURNAL, Vol. 2, No. 2, August 2018

Copyright $\odot 2018$, ISSN: 2580-4278

c. The learner will be difficult to finish the work, if they have first met some new vocabularies.

d. We need to deal not only with a single word lexical items, but also with longer, multi word items.

Vocabulary is also important to express idea or to ask for certain important. If someone has a lack of vocabulary, he or she will find some difficulties in expressing his or her ides in oral or written. In addition, if the learners have a less vocabulary, they cannot access information or knowledge. Moreover, without the words the learner cannot really understand facts or ideas that the learners have met. One should be able to master adequate vocabulary to convey their message.

From those statements, vocabulary is really needed especially for young learners English in learning a foreign language because it helps them to know how to express and understand others idea as well. Students with poor mastery of vocabulary cannot communicate in target language well; consequently they will not be able to infer any ideas transmitted to them.

\section{Vocabulary Mastery}

The vocabulary mastery is a thing that is difficult enough to be defined. Nation (1990:75) states that the mastering of vocabulary is meant to as the ability to heap any words based on their course or study. He also adds that the ability can describe any of words which they recognize before whether in their foreign or mother language. It means, when the students recognize any words, they will learn to heap or mastery it. Then, they will memorize it along with its meaning.

In essence, vocabulary mastery is peoples' ability to use or to understand words of a language that they have learned and heard in certain situations in which they really have experienced the situations in their life.

Vocabulary mastery is a gradual process. To reach out the good vocabulary mastery someone needs to follow the process. It can be defined as through knowledge of the words of a language. The students' vocabulary mastery is indicated by their ability in producing and understanding the words in their daily life.

When the students find the difficult words that they do not know the meaning of related words in a reading text. Vocabulary can give contribution to the students. She can look up the dictionary and check the meaning, another way is to study part of a word which gives clue to the meaning of whole words. The students should identify all the roots, prefix and suffix. For example: the word Transportation. Trans means across from one place to another, and Port means to carry, and ion means state of condition, the prefix that make Verb become noun. So, the meaning of transportation is the state of carrying something from one place to another".

\section{Vocabulary Test}

One of the ways to knowing the students' development or students' understanding about material is through test. Test in simple term is a number measuring person's ability, knowledge or performance in a given domain (Brown, 2004:3). There are many published exercise on vocabulary. These include:

1. Matching picture to words.

For example :Match the picture with their words!

\begin{tabular}{|l|l|}
\hline Picture & Word \\
\hline
\end{tabular}


KAIROS ELT JOURNAL, Vol. 2, No. 2, August 2018

Copyright $\odot 2018$, ISSN: 2580-4278

1.

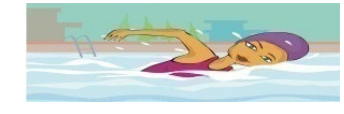

2.

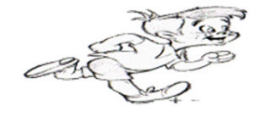

a. Run

b. Swim

2. Matching part of words to other parts.

For example : Match part of words to other parts!

\begin{tabular}{|c|c|}
\hline Word & Defenition \\
\hline $\begin{array}{l}\text { 1. Rainbow } \\
\text { 2. Rain }\end{array}$ & $\begin{array}{l}\text { a. water that falls to the Earth } \\
\text { b. a band of colors found in the } \\
\text { sky after a rainfall. }\end{array}$ \\
\hline
\end{tabular}

3. Matching words of other words, example: synonym, opposites, sets of related words, and ect.

For example :find the synonym for the word below!

\begin{tabular}{|c|c|}
\hline Words & Synonym \\
\hline 1. Choose & a. Bloodless \\
2. Cold & b. Select \\
\hline
\end{tabular}

For example : find the opposite for the word below!

\begin{tabular}{|c|c|}
\hline Words & Opposites \\
\hline 1. Beatiful & a. Short \\
2. Tall & b. Bad \\
\hline
\end{tabular}

For example : Match sets of related words!

\begin{tabular}{|l|l|}
\hline 1. Motorcicyle & a. $\begin{array}{l}\text { a vehicle with two wheels in } \\
\text { tandem, usually propelled by } \\
\text { pedals connected to the rear } \\
\text { wheel by a chain, and having } \\
\text { handlebars for steering and a } \\
\text { saddle like seat. }\end{array}$ \\
\hline 2. Bicycle & $\begin{array}{l}\text { b. } \\
\text { a two-wheeled vehicle, having } \\
\text { a stronger frame than a } \\
\text { bicycle, that is driven by a } \\
\text { petrol engine. }\end{array}$ \\
\hline
\end{tabular}

Several tasks seem to be designed for students working on their own, but can easily be used in class. For the better, teacher should give some test to students appropriate with their situation with their situation and their skill in order to can get the good result in the learning of English language.

\section{Definition of Game}

Thornbury (2002 : 102) states that games are used to plug hoies in lessons which could more usefully be filled with language-rich talk. Neverthless, the fun factor may help make words more memorable, and like it or not, a competitive element often serves to animate even the most lethargic students. Therefore, useful games are those that encourage learners to recall words and preferably at speed.

According to Wright et.al (2006:1) games are an activity which is entertaining and engaging, oftenchallenging, and an activity in which the learners play and usually interact with others. Games help andencourage many learners to sustain their interest and work.Games also

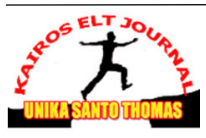


KAIROS ELT JOURNAL, Vol. 2, No. 2, August 2018

Copyright $\odot 2018$, ISSN: 2580-4278

help the teacher to create contexts in which the language is useful and meaningful. The learners want to take part, and in order to do so must understand what others are saying or have written, and they mustspeak or write in order to express their own point of view or give information. Games provide one way of helping the learners to experiencelanguage rather than merely studyit.

From some explanation, it can be argued that games are part of interesting activities, which it can be done in the classroom as a secret plan or trick, so that it entertains for the students, and it also can make the teaching learning process fun, especially either for the teacher or the student.

\section{Types of Language Games}

It is difficult to classify games into categories because such categories often overlap. Hadfield (1999 : 5) explained two ways of classifying language games: First, the author divides language games into two types: linguistic games and communicative games. Linguistic games focus on accuracy; on the other hand, communicative games focus on the exchange of information. Games classified into more detailed forms which are composed of both the elements defining linguistic and communicative games.

a. Sorting, ordering or arranging games. For example, students have a set of cards with months, and they have to arrange those cards in order.

b. Information gap games. In such games, one or more people have information that other people do not, and they have to exchange their information to complete a task.

c. Guessing games. These are a variation on information gap games. For instance, one student who has a flash card cannot show it to others but must instead mime it to others, and then other students have to guess the word from his or her performance.

d. Searching games. These games are another version of two-way information games, with everyone seeking and giving information. For example, everyone is given a clue to find out who the criminal is. They have to ask and then reply to their partners to solve the problem.

e. Matching games. As the name implies, participants need to find a match for a word, picture, or card.

f. Labeling games. These are a form of matching game. The only difference is that the participants match labels and pictures.

g. Exchanging games. Many card games fall into this category. In these games, students barter cards, objectives, or ideas.

h. Board games. "Scrabble" is one of the most popular games $\mathrm{n}$ this category.

i. Role playing games. Such games involve students in playing roles that they might not play in real life. They might also be employed to get students to practice set dialogues.

In this study we contend primarily, with three varieties of gaming types: arranging games, guessing games, and matching games. They are adopted to facilitate students' motivation, confidence, and vocabulary acquisition. More recent studies related to the positive and negative effects of playing games and the subsequent performance of students in measures of English proficiency are discussed in the following section.

\section{The Definition of Words Matching Game}

Words matching game is a kind of game that requires the students to match either the words in the target language with some pictures that describe the definition of the word or the word in the target language with its definition in the students' language. Furthermore, word matching games can be done individually or in group. This game is appropriate to be applied in enriching the students' vocabulary mastery.

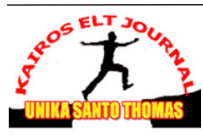


KAIROS ELT JOURNAL, Vol. 2, No. 2, August 2018

Copyright $\odot 2018$, ISSN: 2580-4278

Curran (in Huda 2013 : 251 ) states that word matching game is currently one of the important strategies in the classroom. The purpose of this strategy include: 1. deepening of the material, 2. the excavation material, 3. edutainment. Teachers need to do some special preparation before implementing this strategy. Some preparations include:

1. Make some questions that are appropriate to the material studied (the amount depends on the learning objectives) and then write the cards questions.

2. Make the answers key to the questions that have been created and write the answers in the cards. it would be better if the card question and answer cards of different colors.

3. Create a rule that contains an award for students who work and sanctions for students who fail (here, the teacher can make these rules together with students).

4. Provide a sheet to record the couples who succeed at the same time for the presentation scoring.

Based on the definition, word matching game is a game using cards that consist of two kind of cards that is question card and answer card. The students have to match the answer card to the students in question card based on the changing.

The Advantages of Applying Words Matching Game in Improving Vocabulary Mastery In applying words matching game has many advantages. Advantages of this strategy include:

a. The first is can improve student learning activities, both cognitively and physically because this strategy is fun.

b. The second is improving students' understanding of the material being studied and may increase students' motivation.

c. The third is effective as a means to train students to perform persentations courage.

d. The fourth is effective discipline to train students appreciate the time to learn.

\section{Steps in Implementing Words Matching Game}

Huda $(2013$ : 252) states that there are some steps in implementing a word matching game include:

1. The teacher prepares some cards that contain some concepts or a suitable topic for review session, a part is contains questions and the other is the answer.

2. Every student gets card.

3. Every student thinks the answer or the question from the card that they hold.

4. Every student finds their partner that has a matching card with his card.

5. Every student who finds their suitable card before the time up will get a point.

6. After the first session, the card is changes, so the students will get the different card in the next session. It is continued until this activity is ended.

Teacher together with the students make a conclusion from the material that have been given by teacher.

\section{RESEARCH METHOD}

The research design of this study was Classroom Action Research (CAR). Classroom action research was designed to help the writer to find out what was happening in his or her classroom, and to use that information to make the wise decisions for the future. In this research, the writer was trying to improve students' vocabulary mastery through words matching game. The approach used in the classroom action research could be qualitative or quantitative. In this classroom action research, the researcher used qualitative and quantitative methods to collecting the data. Wallace $(1978: 38)$ defines that qualitative method is used to describe data which cannot be counted or measured in objective way, while quantitative method was broadly used to describe what can be counted or measured.

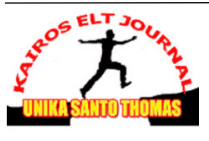


KAIROS ELT JOURNAL, Vol. 2, No. 2, August 2018

Copyright $\odot 2018$, ISSN: 2580-4278

Creswell (2008 : 596-597) states that CAR is the practical design which explores a problem with an aim toward developing a solution to a problem, and also action research designs are systematical procedure done by the teachers (or other individual in an educational setting) to improve their teaching, and their students learning.

\section{DATA ANALYSIS \\ The Qualitative Data \\ Field Notes \\ Meeting I (Pre-test)}

Meeting I was held onThursday, $13^{\text {th }}$ October 2016 started at $07.30-08.10$. Before the start of learning teaching process, the teacher and students prayed together after that the researcher say greet to the students and introduced herself. The researcher explained the purpose of her coming to their school to conduct a research. The researcher told the students that in order to conduct her research, researchers gave the test before the game is applied and the test is referred to as a pre-test. The test was 25 items in multiple matching task and was carried out for 40 minutes. There are 29 students who follow this test, two of the students was absent and one of the students was sick. When the researcher gave the test to be done. Some of the students asked how to do it? the researcher explain how to answer thetest.When the students did the test her collaborator help the researcher. During the students were doing on thetests, they looked confused and difficult to did the test because when they were doing these tests they did not have preparation to done. When the time was up, the researcher collected text that has been done by themafter that the researcher asked the students to pray and say good bye to the students.

\section{Meeting II (Cycle 1)}

Meeting II was held onMonday, $17^{\text {th }}$ October 2016 started at $07.30-09.50$.After pretest was given at the first meeting then at the second meeting the researcher applied the words matching game in the learning teaching process. The second meeting was the beginning of the cycle 1. Before the start of learningteaching process, the researcher and students prayed together after that the researcher say good morning, ask their condition and ask who was absent today then the researcher gave motivatied students to spirit in the learning teaching process. After that the researcher was doing warming up the material to be studied then the researcher ask to the students what was our topic today and the students answer the question the researcher. After the students answer, the researcher told our topic today was "Kinds of Job" and the researcher ask again to the students who knows about kinds of job? Students answer "police, teacher, tailor, doctor, nurse, and pilot". Then the researcher explain kinds of job, meaning of job, the description of job and the researcher explain about how to applied words matching game. After that the researcher and students was doing words matching game during five session and her collaborator took some pictures when the students was doing this words matching game. As long as the game progresses, the students looked very happy, but they were also looking confused to foundtheir partner. The researcher gave point to the students who do it right. In the first session the researcher gave 20 point to the winning pair. After the words matching game was finished and the time was up the researcher ask say good bye to the students.

\section{Meeting III (Cycle 1)}

Meeting III was held onThursday, $20^{\text {th }}$ October 2016 started at $07.30-09.50$. In the third meeting the researcher taught the new topic because the topic kinds of job have been finished in second meeting. Before start to new topic the researcher students prayed together after that the researcher say good morning, ask their condition and ask who was absent today

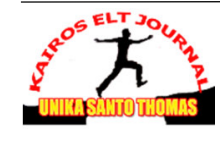


KAIROS ELT JOURNAL, Vol. 2, No. 2, August 2018

Copyright $\odot 2018$, ISSN: 2580-4278

then the researcher gave motivatied students to spirit in the learning teaching process. Then the researcher ask to the students did you still remember about our lesson yesterday? Students answer yes miss. Now what do you remmeber it. Students answer kinds of job. After the researcher review the lesson yesterday the researcher was doing warming up in new topic. Then the researcher ask again what was topic today. After the students answer, the reseacher said our topic today was "things in the classroom". The researcher explain the meaning of things in the classroom and shown the some pictures about things in the classroom. After the researcher finished explain about it the researcher ask students to did words matching game such as in the second meeting. After words matching game finished the researcher ask some students make conclusion about lesson today and when time was up the researcher say good bye.

\section{Meeting IV ( The End Cycle 1)}

Meeting IV was held onMonday, $24^{\text {th }}$ October 2016 started at $07.30-09.50$. The fourth meeting was the end of the cycle 1 . Before the start of learning teaching process, the researcher and students prayed together after that the researcher say good morning, ask their condition and ask who was absent today then the researcher gave motivatied students to spirit in the learning teaching process. The researcher ask to the students did you still remember about our lesson yesterday? Students answer yes miss. Now what do you remmeber it. Students answer things in the classroom. The researcher review the lesson had been learn yesterday. After that the researcher and the students was doing words matching game during 40 minutes and her collaborator took some pictures. The researcher asked the students to did the test in which the test was test after in cycle 1 finished (formative test cycle 1). The test was 25 items in multiple matching task and was carried out for 40 minutes. During the students were doing on thetests, they looked enjoyable but they made noise. When the time was up, the researcher collected text that has been done by them after that the researcher asked the students to pray and say good bye to the students.

\section{Meeting V (Cycle 2)}

Meeting IV was held onThursday, $27^{\text {th }}$ October 2016 started at $07.30-09.50$. The fifth meeting was the beginning of the cycle two. The researcher and her collaborator entered the classroom together. The researcher entered the class and directly greeted the students. The researcher checked the students' attendance list. The researcher was doing warming up about topic adjectives to describe people. After that the researcher explain adjectives to describe people while the researcher explained, her collaborator took some pictures. In the fifth meeting the researcher gave some exercise form multiple matching choice after the researcher had been finished explain the new material. In this meeting more increased than the previous meeting because they were fun to applied words matching game. The researcher ask some students made conclusion about lesson today and when time was up the researcher closed the activities and the researcher say good bye.

\section{Meeting VI (Cycle 2)}

Meeting VI was held onMonday, $31^{\text {th }}$ October 2016 started at $07.30-09.50$. The writer and her collaborator entered the classroom together. Before the start of learning teaching process, the researcher and students prayed together after that the researcher say good morning, ask their condition and ask who was absent today then the researcher gave motivatied students to spirit in the learning teaching process. The researcher ask to the students did you still remember about our lesson yesterday? Students answer yes miss. Now what do you remmeber it. Students answer adjectives to describe people. The researcher explain again about the material and shown the meaning and the picture about adjectives. The researcher give some exercise to did it and answer together. After that the researcher ask the students to did words

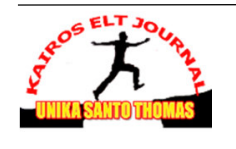


KAIROS ELT JOURNAL, Vol. 2, No. 2, August 2018

Copyright $\odot 2018$, ISSN: 2580-4278

matching game. As long as the game progresses, the students looked very happy and they easier to found their partner. During the games, her collaborator took some pictures. When the bell was rang the researcher ended their lesson, the researcher made conclusion with the students and the researcher says good bye.

\section{Meeting VII (Cycle 2)}

Meeting VI was held onMonday, $4^{\text {th }}$ November 2016 started at $07.30-09.50$. Before the start of learning teaching process, the researcher and students prayed together after that the researcher say good morning, ask their condition and ask who was absent today then the researcher gave motivatied students to spirit in the learning teaching process. The researcher ask to the students did you still remember about our lesson yesterday? Students answer yes miss. Now what do you remmeber it. Students answer things in the adjectives to describe people. The researcher review the lesson had been learn yesterday. During the seventh meeting the researcher and the students was doing words matching game until the lesson finished. After that the lesson finished the researcher and the students made conclusion. Then the researcher closed the learning teaching process and says good bye. The cycle 2 has been done.

\section{Meeting VIII ( Post-test )}

Meeting VI was held onMonday, $7^{\text {th }}$ November 2016 started at $07.30-08.10$. The eighth meeting was the last meeting for the classroom action research.Posttest was done in this last meeting. It was 25 items and carried out for 40 minutes. The researcher believed that the students' score would get improved. The research was done well in eighth meeting. The Field notes showed that the teaching learning process was carried out well. The students were very active, excited and interested in learning vocabulary by using word matching game technique, even sometimes the situation in the classroom was noisy because the students always asked the researcher about the difficult words.

\section{The Observation Sheet}

The observation sheet was made by researcher to be checked by the teacher who observed the teaching learning process in the cycle 1 and cycle 2 (could be seen in the appendix). The result showed the observation of the researcher which was focused on the situation of teaching learning process. We could see that there was an improvement from cycle 1 in to cycle 2. The students did not participate, did not ask the unclear lesson thy found. It happened because the researcher was a new comer to them so that they were just be quite and follow what the researcher asked to did.

However, in cycle two after the students learning vocabulary by using word matching game they feel enjoy, fun and motivated to memorize and learning English. It seen from their enthusiastic and interested in the lesson whiles the teaching learning process and the increase of their understanding and memorizing from their score.

\section{The Quantitative Data}

The quantitative data was taken from the results of two cycles, namely cycle 1 and cycle 2 which were conducted in eight meetings. It means that there were two vocabulary tests in two cycles. Besides, a pretest was also administered to the students before the action and posttest after the action. In the middle, there was a formative test after cycle 1.The scoring of the students from the pre-test, formative test cycle 1 and post-test. The score improvement could be seen in below.

Table 1. Pre-test Rank

\begin{tabular}{|l|l|l|}
\hline No & Category & Students Score \\
\hline \hline
\end{tabular}


KAIROS ELT JOURNAL, Vol. 2, No. 2, August 2018

Copyright $\odot 2018$, ISSN: 2580-4278

\begin{tabular}{|l|l|l|}
\hline 1 & The highest score & 76 \\
\hline 2 & The average score & 49.03 \\
\hline 3 & The lowest score & 16 \\
\hline
\end{tabular}

Based on the table 1, the data showed showed that the mean of pretest was49.03. There were only one students who got the highest score 76 and only one students who got the lowest score 16. It can be concluded that the students' understanding of vocabulary mastery was still low.

Table 2. The Data Frequency forStudents' Score in Pre-test

\begin{tabular}{|l|l|l|l|l|l|}
\hline No & $\begin{array}{l}\text { Score } \\
\text { Interval }\end{array}$ & $\begin{array}{l}\text { Frequency of } \\
\text { the Students }\end{array}$ & Percentage & $\begin{array}{l}\text { The } \\
\text { Quality }\end{array}$ & Category \\
\hline 1 & $85-100$ & 0 & $0 \%$ & A & Very high \\
\hline 2 & $70-84$ & 1 & $3.45 \%$ & B & High \\
\hline 3 & $60-69$ & 7 & $24.14 \%$ & C & Average \\
\hline 4 & $50-59$ & 6 & $20.69 \%$ & D & Low \\
\hline 5 & $0-49$ & 15 & $51.72 \%$ & E & Very low \\
\hline & Total & 29 & 100 & & \\
\hline
\end{tabular}

Based on the frequency of the students' score pre-test, there was no students who got category very high. Among 29 students only one student who passed the Minimal Criterion Mastery (KKM). It was 3.45\% in categories high. And the other students who still get the score below the Minimal Criterion Mastery (KKM). There were 7 students who gotaverage score, it was $24.14 \%$. 6 students who got low score, it was $20.69 \%$. And 15 students who got very low score, it was $51.72 \%$. In this pretest there were 29 students who followed, two of students was absent and one student was sick. It could be conclud that the students' understanding of vocabulary mastery was still low. Therefore, the writer was conducted the Classroom Action Research (CAR) by using Word Matching Game in each cycle are important to improve the students' result.

Table 3. Formative Testin Cycle 1 Rank

\begin{tabular}{|l|l|l|}
\hline No & Category & Students Score \\
\hline 1 & The highest score & 100 \\
\hline 2 & The average score & 73 \\
\hline 3 & The lowest score & 52 \\
\hline
\end{tabular}

Based on the table 3, the datashowed that the mean score is73.Only one students got the highest score100, and four students got the lowest score52. It can be concluded that the students' active, and interesting learn by using Words Matching game.

Table 4. The Data Frequency for Formative Test Scorein Cycle 1

\begin{tabular}{|l|l|l|l|l|l|}
\hline No & $\begin{array}{l}\text { Score } \\
\text { Interval }\end{array}$ & $\begin{array}{l}\text { Frequency of } \\
\text { the Students }\end{array}$ & Percentage & $\begin{array}{l}\text { The } \\
\text { Quality }\end{array}$ & Category \\
\hline 1 & $85-100$ & 5 & $15.62 \%$ & A & Very high \\
\hline 2 & $70-84$ & 15 & $46.88 \%$ & B & High \\
\hline 3 & $60-69$ & 7 & $21.88 \%$ & C & Average \\
\hline 4 & $50-59$ & 5 & $15.62 \%$ & D & Low \\
\hline 5 & $0-49$ & 0 & $0 \%$ & E & Very low \\
\hline & Total & 32 & 100 & & \\
\hline
\end{tabular}

Based on the frequency of the students score after the teacher taught by using words matching game in formative cycle 1 , there were 5 students got very high score $(15.62 \%)$,

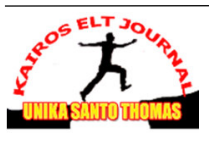


KAIROS ELT JOURNAL, Vol. 2, No. 2, August 2018

Copyright $\odot 2018$, ISSN: 2580-4278

15 students gothigh score $(46.88 \%)$, 7 students got average score $(21.88 \%)$ and $5(15.62 \%)$ students got low score. It means that words matching game could improved the ablity students in learning vocabulary mastery.

Table 5. Post-test End Program Rank

\begin{tabular}{|l|l|l|}
\hline No & Category & Students Score \\
\hline 1 & The highest score & 100 \\
\hline 2 & The average score & 77.84 \\
\hline 3 & The lowest score & 60 \\
\hline
\end{tabular}

Based on the result of Post - testshowed that the mean score was 77,84.Two students got the highest score was 100, and four students got the lowest score was 60 . It can be concluded that the students' understanding of vocabulary mastery by using wordsmatching game could improved.

Table 6. The Data Frequency for Post-test End Program

\begin{tabular}{|l|l|l|l|l|l|}
\hline No & $\begin{array}{l}\text { Score } \\
\text { Interval }\end{array}$ & $\begin{array}{l}\text { Frequency of } \\
\text { the Students }\end{array}$ & Percentage & $\begin{array}{l}\text { The } \\
\text { Quality }\end{array}$ & Category \\
\hline 1 & $85-100$ & 7 & $21.87 \%$ & A & Very high \\
\hline 2 & $70-84$ & 17 & $53.13 \%$ & B & High \\
\hline 3 & $60-69$ & 8 & $25 \%$ & C & Average \\
\hline 4 & $50-59$ & 0 & $0 \%$ & D & Low \\
\hline 5 & $0-49$ & 0 & $0 \%$ & E & Very low \\
\hline & Total & 32 & 100 & & \\
\hline
\end{tabular}

Based on the frequency of the students score post-test, there were24students who passed the Minimal Criterion Mastery (KKM). And eightstudents who still get the score below the Minimal Criterion Mastery (KKM).There were 7 students got the very high category, it was $21.87 \%$. 8 students got the average category, it was $25 \%$. The conclusion of the table was that in the post-test the students' vocabulary improved. Most of the students got the high categorize, namely 17 students or it is $53,13 \%$. It was better than the pre-test which was very low, and it was better than cycle 1 . The pre-test score were lower than the formative test in cycle 1score and the last test namely pos-test end program was higher than formative test in cycle 1.

The result of students' mean score and the percentages could be seen in below:

Table 7. The Mean Score of the Students Test

\begin{tabular}{|l|l|}
\hline Test & Mean score \\
\hline Pretest & 49.03 \\
\hline Formative test cycle 1 & 73 \\
\hline Post test end program & 77.84 \\
\hline
\end{tabular}

Based on the table 7, it showed that the mean of the students' score in vocabulary mastery was improvement. In the pre-test the mean was 49.03, in formative test cycle 1 the mean was 73 and then in post-test cycle 2 the mean was 77.84. It was proved that the students' vocabulary mastery score was improved after using the words matching game in taught the students.

Table 8. The Percentage of the Students got Up 70

\begin{tabular}{|l|l|l|}
\hline Test & Number of Students & Percentage \\
\hline
\end{tabular}

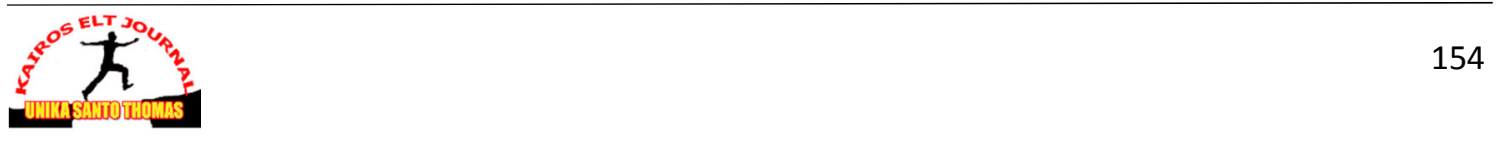


KAIROS ELT JOURNAL, Vol. 2, No. 2, August 2018

Copyright $\odot 2018$, ISSN: 2580-4278

\begin{tabular}{|l|l|l|}
\hline Pre-test & 1 & $3.44 \%$ \\
\hline Formative test cycle 1 & 20 & $62.5 \%$ \\
\hline Post-test & 24 & $75 \%$ \\
\hline
\end{tabular}

The result of study showed the improvement of the score from the first test (pre-test) to the second test (formative test cycle 1) and the last test (post-test end program). The first test (pre-test) was administreted to the students, there was one students got the score above 70 or $3.44 \%$. In the second test (formative test cycle 1), there were $62.5 \%$ or 20 students who got score above 70 . It could be seen that from the first test to the second test there was improvement. The percentage in the first test got 3.44\% while the percentage in the second test got $62.5 \%$ in this statesment there was improve in used words matching game. In the last test (post-test end program), there were $75 \%$ or 24 students got score above 70 . It mean that there was improvement of the students' vocabulary mastery score from the pre-test to the last posttest. We could compare the pre-test score and the post-test score from $3.44 \%$ became $75 \%$. It could be concluded that there was improvement between pre-test and post-test. So that words matching game could improve students' vocabulary mastery.

Increasing the students score in learning vocabulary through words matching game could be seen from the mean and the percentage of the students in each test. The researcher used formula to count the mean and the percentage in each test. The formula to find the mean and the percentage, we could be seen in appendix 2 .

\section{Research Findings}

As a whole, the research findings of the data result among the pre-test, the formative test in cycle 1 and the post-test of cycle 2 are as following: In the pre-test, the mean score of the students on vocabulary test before carrying out CAR is 49.03. It was the result of students' score before the using of word matching game. Meanwhile, the percentage which passes the Minimal Criterion Mastery (KKM) was 3.44\%. It means that there was only one student who was able to pass the Minimal Criterion Mastery (KKM), and there were 28 students who were not able to pass the Minimal Criterion Mastery (KKM).

Morever, the mean score in the formative test in cycle 1 was 73 . It means that the improvement result of the implementing between pre-test and formative test in cycle 1 is 23.97. The percentage which passes the Minimal Criterion Mastery (KKM) was 62.5\%. It means that there were 20 students who was able to pass the Minimal Criterion Mastery (KKM), and there were 13 students who were not able to pass the Minimal Criterion Mastery (KKM).

Afterwards, the mean score in the post-test cycle 2 was 77.84. It shows that the improvement result of the implementing between pre-test and post-test cycle 2 was 28.81 . The percentage which passes the Minimal Criterion Mastery (KKM) was $75 \%$. It means that there were 24 students who was able to pass the Minimal Criterion Mastery (KKM), and there were 8 students who were not able to pass the Minimal Criterion Mastery (KKM). So, it could be concluded that the students' score was a significant improvement.

\section{Discussion}

Word Matching Game was applied to improve students' vocabulary mastery. Word Matching Game was one of many game that could make the students easier in learning English especially in vocabulary mastery. This research proved effectiveness of applyingword matchinggame. It was shown in table 4.7, the mean of each test, the pre-test mean was49.03, theformative testin cycle 1 mean was 73 and the pos-test end program was 77,84 . There was improvement between the pre-test and post-test.

It could be also seen from the table 4.8 students' score in the last test (post-test end program) was significantly higher than the first test (pre-test). In the first test (pre-test) who

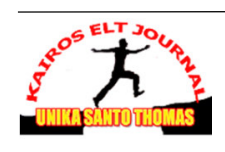


KAIROS ELT JOURNAL, Vol. 2, No. 2, August 2018

Copyright@2018, ISSN: 2580-4278

followed the test was 29 students and among 29 students only one students who gots score above 70 . In the second test (formative test cycle 1), 32 students who followed the test and there were 20 students who passed the Minimal Criterion Mastery (KKM) and the other students only got $21.88 \%$ or the average category. In the last test (post-test end program), 32 students who followed the test and there were 24 students who passed the Minimal Criterion Mastery (KKM) or who got score above 70. It can be concluded that the use of words matching game could improve students' vocabulary mastery.

The problem was found by researcher when the implementing the words matching game were the students made noise when they searched answers and questions card to other friends, sometimes they did not listen the instruction who the researcher said and they always hurry to start the game.

\section{CONCLUSIONS}

Based on the result of the research that was conducted in the first grade students of SMP Santo Petrus Medan in academic year 2016 / 2017. It can be concluded that using word matching game could improve students' vocabulary mastery. It could be seen from the following fact.

The first, related to the test result, the researcher concluded that there were the mean of each test, there was 28.81 improvement of students' mean score from pre-test to the post-test end program. In the pre-test, there was one students who passed the Minimal Criterion Mastery (KKM) then in the formative test in cycle 1, there were 20 or $62.5 \%$ students in the class who passed the Minimal Criterion Mastery (KKM). Next in the result of post-test end program, there were 24 or $75 \%$ students who passed the Minimal Criterion Mastery (KKM). It can be concluded that the use of words matching game could improve students' vocabulary mastery.

The second, the observation result showed that the students were more active and interest in learning vocabulary through words matching games, because words matching game could make have fun, and help them learn vocabulary easily.

\section{BIBLIOGRAPHY}

Brown, H.Douglas.2004. Language Assessment Principles and Classroom Practice. Longman: Pearson Educational.

Burns, Anne. 2010. Doing Action Research in English Language Teaching:A Guide for Practioners. Sydney: Macquaric University.

Creswell, John W. 2008. Education Research. London: Person Educational International.

Derakhshan, Ali and Elham D Khatir. 2015. The Effect of Using Games on English Vocabulary Learning. Journal of Applied Linguistics and Language Research, 2 (3) 39.

Hadfield, Jill. 1999. Intermediate Vocabulary Games. Longman: Pearson Educational Limited.

Huda, Miftahul. 2013. Model-Model Pengajaran dan Pembelajaran. Yogyakarta: Pustaka Pelajar.

Iriyani, Ade. 2013. Improving Students' Vocabulary Achievement through Make a Match Method. A Thesis, Medan, English Department. Faculty of Language and Arts. State University of Medan

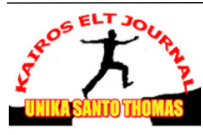


KAIROS ELT JOURNAL, Vol. 2, No. 2, August 2018

Copyright $\odot 2018$, ISSN: 2580-4278

Lewis, Gordon and G. Bedson. (1999). Games for Children. Oxford: Oxford University Press.

Limbong, T. (2013). Pemanfaatan visualisasi dan animasi untuk kegiatan akademik sebagai sarana pengumuman pada stmik budi darma medan. Informasi Dan Teknologi Ilmiah.

Nation, I.S.P. 1990. Teaching and Learning Vocabulary. Boston: Heinle \& Heinle.

Nation, I.S.P. 2013. “What is Vocabulary?”. In Nunan, D. (3 ${ }^{\text {rd }}$ Ed). Practical English Language Teaching. New York: Mc Graw-Hill.

Schmitt, N. 2000. Vocabulary in Language Teaching. New York: Cambridge University Press.

Scrivener, Jim. 1994. Learning Teaching: A Guidebook for English Language Teachers.London: McMillan.

Thornbury, Scott. 2002. How to Teach Vocabulary. London: Pearson Education Limited.

Uswatun H, Dian. 2015. The Use of Words Matching Game in Improving Students' Vocabulary. Sarjana's Thesis, Teaching Training and Education Faculty : Mataram University. Unpublished.

Wallace, Michael J. 1978. Action Research for Language Teachers. Cambridge: Cambridge University Press.

Willis, Judy. 2008. Teaching the Brain to Read. Alexandria: Association for Supervision and Curriculum Development (ASCD).

Wright, Andrew et.al. 2006. Games for Language Learning. Cambridge: Cambridge University Press. 